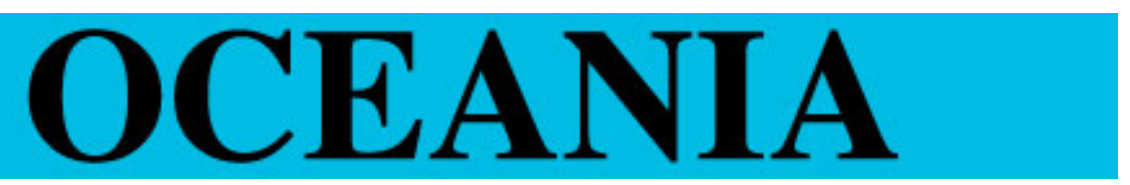

Oceania, Vol. 83, Issue 3 (2013): 175-191

DOI:10.1002/ocea.5019

\title{
The Magic of Money and the Magic of the State: Fast Money Schemes in Papua New Guinea
}

\author{
John Cox \\ Australian National University
}

\begin{abstract}
As Keith Hart (1986) articulated in his neat phrase 'two sides of the coin', money and the state are inextricably intertwined. However, academic discussions of the state tend to fall under the heading of 'governance', with implicit reference to democratic ideals, while money is regarded as 'economics', a field dominated by ideas of the market. In this paper, I use material from U-Vistract, a mass Ponzi scam to show how quasi-magical ideas of money and wealth have grown out of the disillusioning experience of the state in its failure to deliver 'development'. These imaginings of prosperity entail a different kind of state, based on the moral reform of Christian citizens and political leaders and the reorientation of the banking system to deliver benefits to ordinary people. As the Royal Kingdom of Papala, U-Vistract sought to be seen to be like a Christian state and so deceived its investors into thinking that they were participating in a moral project that would allow them to redress the short-comings of the Papua New Guinean state. As the scam took on the appearance of the state, so the state came to be seen as a scam.
\end{abstract}

Keywords: fraud, scams, Christianity, Papua New Guinea, governance, development.

\section{INTRODUCTION}

Ponzi schemes ${ }^{1}$ are remarkable articulators of fantasies about money and wealth. They also articulate expectations of state and nation that make fantasies of wealth plausible for investors. This article explores some of the reasons for this in relation to a recent spate of fast money schemes in Papua New Guinea. These scams were not marginal events. Indeed, they were central to public life, attracted hundreds of thousands of investors, and ended up as a wellreported public scandal, in much the same ways as occurred with Bernie Madoff and Charles Ponzi. Scams are typically dismissed as the consequence of greed and gullibility and are left at the margins of the public realm without reflecting on what common regimes of knowledge might link a Ponzi scheme with other official practices of investment. However, as Verdery (1995) and Musaraj (2011) demonstrate for pyramid scams in Eastern Europe, Ponzi schemes can represent the nation because they offer a narrative of unfettered access to modernity that draws on the unfulfilled promises of the state and mimics state rituals of bureaucracy, not least in relation to money. Likewise, the Madoff scam, unravelled at the height of the global financial crisis, became read as a ready metaphor for the disastrous failure of the state to oversee the financial systems, if not more starkly as a metaphor for the deceptions at the heart of capitalism (Comaroff and Comaroff 1999). In this case, I will describe how the fast money scheme in PNG called U-Vistract took up the project of becoming like a state - the Royal Kingdom of Papala (henceforth Papala) - and did so in ways that foregrounded how narratives of finance, investment and money are integral elements of the magic of the state. 


\section{THE FAST MONEY RUSH AND THE STORY OF U-VISTRACT}

In the late 1990s, Port Moresby, the capital of PNG, was abuzz with stories of 'fast money schemes'-Ponzi schemes that promised $100 \%$ returns on investments within a month. As with similar scams worldwide, the PNG fast money schemes generated great curiosity and excitement and, for a while, drew in so many investors that they could pay those first in line or on the 'inside track' (Verdery 1995). The schemes recruited investors by word of mouth and, by recirculating their money, appeared to give evidence that their outrageous claims 'really worked' (Cox 2012). Fifteen years on, only one of the fast money schemes is still in operation: U-Vistract Financial Systems. U-Vistract and its feeder schemes, such as Money Rain, gulled as many as 200,000 investors within PNG, defrauding them of perhaps 1 billion Kina. ${ }^{2}$ The scheme is now reduced to a small number of followers in Bougainville, although it is still active on line and has fooled several American investors through its websites.

Marie, a Bougainvillean in her early 30s now teaching science at a secondary school in Port Moresby, describes how she became involved in U-Vistract when working at a boarding school outside Mount Hagen in 1999. Her account captures the urgency of the rush to invest in the schemes:

Everyone I knew was in it at that point. My uncle said, 'Just try it!' I came to Moresby on school holidays with K2000 for my expenses and I decided to put in K1000. Having the knowledge that it's impossible, I waited one month and took it. I wanted to try it to see if it's really true but I didn't believe it. When I got my K1000 back I was so happy but I wished I had more and invested earlier. I needed the money and wanted it back. I didn't have to join the long lines because they were my relatives and invested for me. I was counting down the month to my payment and I was worried that I wouldn't get my money but it came. Then I reinvested K1000. I went back to the Highlands and I had this paper saying how much you have and I left it with my uncles to rollover for me. It didn't last that long after that, maybe four to six months. By the time I went to get money out again, they weren't giving any out, just taking money.

U-Vistract has been through several incarnations: it began in 1997-8 as a 'Bank for Bougainvilleans' recovering from the social and economic devastation left by ten years of violent conflict over mining. The Bougainville conflict had formally ended with a ceasefire in 1997 after the PNG Government's failure in using force to re-establish control of the island (Regan 2010). Prominent Bougainvilleans in Port Moresby celebrated the founder, Noah Musingku, as Bougainville's first international financier (Regan, unpublished manuscript 2009). President of the Bougainville People's Congress, Joseph Kabui, described the 'fast money schemes' as 'a window of hope' for rural Bougainville (Post-Courier 26 Aug 1999). As U-Vistract's reputation grew, it broadened out to take 'investments' from other Papua New Guineans and even foreigners.

U-Vistract also spread among the political elite. There are many stories of politicians and high-level public officers investing state money in the schemes (Cox 2012). In July 1999, then Prime Minister Bill Skate and his Treasurer Iairo Lasaro gave the fast money schemes exemption from the Financial Institutions Act. This would have allowed them to operate with impunity, but Skate was ousted by Sir Mekere Morauta later that same month. Morauta, a former Bank of PNG Governor, acted quickly against the schemes. In September 1999, the schemes were ordered to present their financial records and pay their investors within three months. This hastened the inevitable collapse of the schemes but left many investors blaming the loss of their money on the government, not the scams. 
Pauline is a Bougainvillean teacher living in Madang. In 1999 she invested in U-Vistract with the intention of paying off the mortgage on a house in Port Moresby that she owned with her sisters. Now Pauline recognises U-Vistract as a fraud. Here she recalls her dismay at the failure of the scheme and how she blamed the Government:

I never realised it! Until they stopped it. I guess I'm not one of the first ones to join. I joined and within a month the government closed the scheme and the warnings started to come. But for most people they thought, "This is real, so why is the government doing this? People felt they were benefitting from it, so why is the government trying to close it?" They were basically not happy with the direction the government had given. They were benefitting, definitely the ones higher up in the hierarchy they were benefitting, maybe putting in government money for a week or two. I don't know where they got the money from, from their slush funds.

The scheme spread through churches, particularly the big Pentecostal congregations of Port Moresby (Gibbs 2005). These churches teach 'prosperity theology' (see below), which has high expectations of a 'this-worldly' material benefit that complements the promises of fast money schemes. This teaching has made Pentecostals particularly vulnerable to this kind of scam, more so here since U-Vistract used the vocabulary of Christian prosperity (Bainton and Cox 2009; Cox 2012; cf. Comaroff 2009). Indeed, as U-Vistract crashed it intensified its religious rhetoric and reinvented itself as a 'Christian ministry' stating that 'only born again Christians will be paid' (Post-Courier 31 May 2001). Having lost the state patronage under which it had flourished, U-Vistract intensified its critique of the state, drawing on popular narratives of disillusionment and corruption and their accompanying Christian moral reproaches of political leaders (see below; Gibbs 2005).

As Papala, U-Vistract began to present itself as the financial foundation of a new state. In 2002, having attempted to re-launch the scheme in Port Moresby, Musingku fled to Honiara in Solomon Islands. Here he tried to sign an agreement with the Solomon Islands Government but this failed and in 2003, he returned to his natal village, Tonu in the Siwai District of South Bougainville. There Musingku sought an alliance with Francis Ona, the separatist leader who had declared himself leader of the independent Republic of Me'ekamui in 1998 (Hermkens, this special issue). South Bougainville is not a place where any state has a 'monopoly of violence' and Musingku primarily needed Ona's protection. Musingku persuaded Ona not only to invest substantial amounts of money in U-Vistract but also to be crowned King of Me'ekamui with Musingku as King David Pei II of Papala. The relationship between Musingku and Ona eventually broke down in the face of Musingku's failure to deliver on his promises. Despite attempts on his life, Musingku remains in Tonu, attended by an everdiminishing number of followers and occasionally testing the waters to see if the Autonomous Bougainville Government (ABG) will include him in a reconciliation process. From the apparent isolation of South Bougainville, U-Vistract maintains communications with its agents across PNG, who continue to assure those investors who still hold out hope of seeing their money again that their patience will be rewarded.

\section{GRASRUTS, ELITES AND WORKING CLASS}

My fieldwork was among middle class Papua New Guineans in Madang and Port Moresby: urban salaried people who often refer to themselves as the 'working class', distinguishing themselves from subsistence 'grassroots' workers who do not work in the sense of receiving salaries or regular payments for services (Reed 2003: 63; cf. Macintyre 2011). Papua New 
Guineans regularly divide the country into 'grassroots' and 'elites'. Where urban wage earners were once regarded as straightforwardly 'elite', increasingly, middle class budgets are coming under strain, even at the higher end of incomes. The working class are hardly elite when compared with senior public servants, powerful politicians and landowner rentier millionaires who capture the benefits of resource developments. Indeed, part of the discourse of the working class in PNG consists in complaints about the cost of living in towns and the inadequacy of ordinary wages to meet basic costs (Monsell-Davis 1993: 57-8). The working class may be better described as the 'working poor'. Many live in a financial world of low salaries, bribes, competing demands and rely on 'loan sharks' to live from pay to pay (Goddard 2005: 121-148; Gewertz and Errington 2010: 110 n19; Post-Courier 20 Sep 2007). Even well-salaried Papua New Guineans supplement their income with subsistence contributions from their own gardens or from rural kin. Many try to set up family members in small enterprises to expand the sources of household income. In this daily effort to manage money, the lines between licit and illicit blur and fast money schemes become one of many possibilities of accessing more money (Bainton 2011).

In the face of rising costs of living, deteriorating housing stock and faltering services, discourses of nation and citizenship that previously included the working class are becoming embittering. Koim's (2009) letter to the editor of the Post-Courier, the older of PNG's two daily English language newspapers, articulates a common complaint that ordinary workers are losing out as politicians and high level public servants capture the nation's wealth in generous pay rises and other perks. While elites prosper, desperation drives lower level public servants into debt, corruption, bribery and fraud. Koim is one of many Papua New Guineans who feel that the egalitarian ideals of the independence era have been betrayed: 'Is this what the Preamble to the Constitution of Papua New Guinea speaks about ... "our national wealth, won by honest, hard work be shared equitably by all"? A simple public servant who earns around K500 (net) pay finds it very hard to survive with his family in a city like Port Moresby and reach another pay day' (Koim 2009). The reference here to the national Constitution is both typical of such working class laments and indicates a widespread concern with the failure of the developmental state in PNG.

\section{THE BLESSINGS OF A RICH COUNTRY}

This feeling that even those who should be reasonably well off are not benefitting from a government system where corrupt elites capture the benefits is very widespread. Indeed, it is national in both extent and content. Similar to the 'negative nationalism' described by Robbins (2004a), the 'cultural intimacy' of PNG nationalism is often expressed as a critique of inequality and corruption in the post-colonial nation and as a profound disappointment that the ideals articulated at Independence have not been realised. The 'government system' excludes the people where it should be manifest in national egalitarian development. These laments are articulated by Balthasar, one of the coordinators of U-Vistract in Madang:

I don't know if it is a money scheme. I've only read from the Papala Chronicles. In my opinion from the Director, they say PNG is a rich country but in actual fact there are a lot of poor people around. So he wanted to make something to help people live an equal life. The Founder is a God-fearing man and reads the Bible every day, so that's why we believe the Man Above is guiding and directing him, giving him wisdom.

Really in PNG, it's very hard for the people. The government system is very hard for the people. They have microbanks but there is no good road system, schools, health 
centres. People get about in grass skirts. That's the whole view of the people because they don't benefit from the government system and the banks they set up.

Balthasar and his wife Rebecca live and work in Madang town and have family from different parts of the province. They are both well-educated and identify as working class in the contemporary PNG idiom. Balthasar works in a clerical job with Madang Province. Rebecca is a teacher. They were initially drawn into U-Vistract after seeing other people receiving payments and have been members for some ten years. They initially deposited K4000 with the intention of building up enough money to buy a new car. Despite not receiving any returns on this supposed investment, they continue to believe that the scheme will pay its investors and supporters. Since 2007, they have been organising U-Vistract meetings in Madang.

Balthasar's critique of the nation positions U-Vistract as the answer to social inequality and underdevelopment. Banks are part of the 'government system' that fails the people and stops PNG from realising its potential as a 'rich country'. U-Vistract re-founded the nation in Christian faith and so offered compelling moral grounds for the reinvigoration of the hopes of national development. U-Vistract offered a Christian reform and replacement of the government system, led by the 'God-fearing' Noah Musingku. As we shall see below, U-Vistract took this disillusionment with the national project of development and promised access to the benefits of modernity that the state had historically failed to deliver.

While Balthasar himself is Lutheran, not Pentecostal, the influence of Neo-Pentecostal prosperity theology can be detected here. Riches follow not so much from disciplined hard work (as per Weber's rendering of Calvinism and capitalism) but from having faith in a generous God who bestows material abundance on those who trust him (Comaroff 2009; Robbins 2004b). Rev Dr Creflo Dollar, a black American televangelist, is a proponent of this type of theology and is broadcast on EMTV, PNG's national television station. ${ }^{3} \mathrm{~A}$ friend in Madang subscribes to Dollar's magazine and receives dozens of copies at a time which he distributes at Modillon Hospital where he works. A few months after U-Vistract officials had publicly declared, 'U-Vistract will not pay its investors until they become born-again Christians' (Post-Courier 31 May 2001), Dollar visited PNG. ${ }^{4}$ This account (Figure 1) of Dollar's well-attended rally in Port Moresby appeared in the National (10 Dec 2001), one of the two English language daily newspapers:

Like U-Vistract, Dollar grounded his version of entrepreneurial Christian prosperity in disappointment with PNG's economic development. In this newspaper report, PNG is destined to have abundant prosperity, evoking Biblical descriptions of Israel as a 'land flowing with Milk and Honey' and should therefore be free from poverty. Poverty seems to be the result of a lack of faith. PNG Christians need to take up the entrepreneurial challenge to 'step out in faith and do business'. This thinking reflects a distinctive Neo-Pentecostal magic of money, where money is produced by faith in God and where prosperity is identified with entrepreneurial capitalism (Gifford 2001; Robbins 2004b). Indeed, Dollar takes the soteriological argument in Romans 5 and applies this to the world of money, pronouncing God to be a 'debt-cancelling God', where this is not simply a metaphor for sin but is applied to material and pecuniary concerns. Such literalist exegesis is typical of prosperity theology (Coleman 2000; Gifford 2001). Cancellation of monetary debt as an accompaniment to the forgiveness of sin occurs not only at the individual level but at the national scale: 'Dr Dollar also declared PNG and the believers to be debt-free'. Just as money is denominated in national currency, so, for Dollar and his fellow-travellers, the prosperity of believers is linked to the destiny of the nation. The magic of money seems to require the magic of the state. 


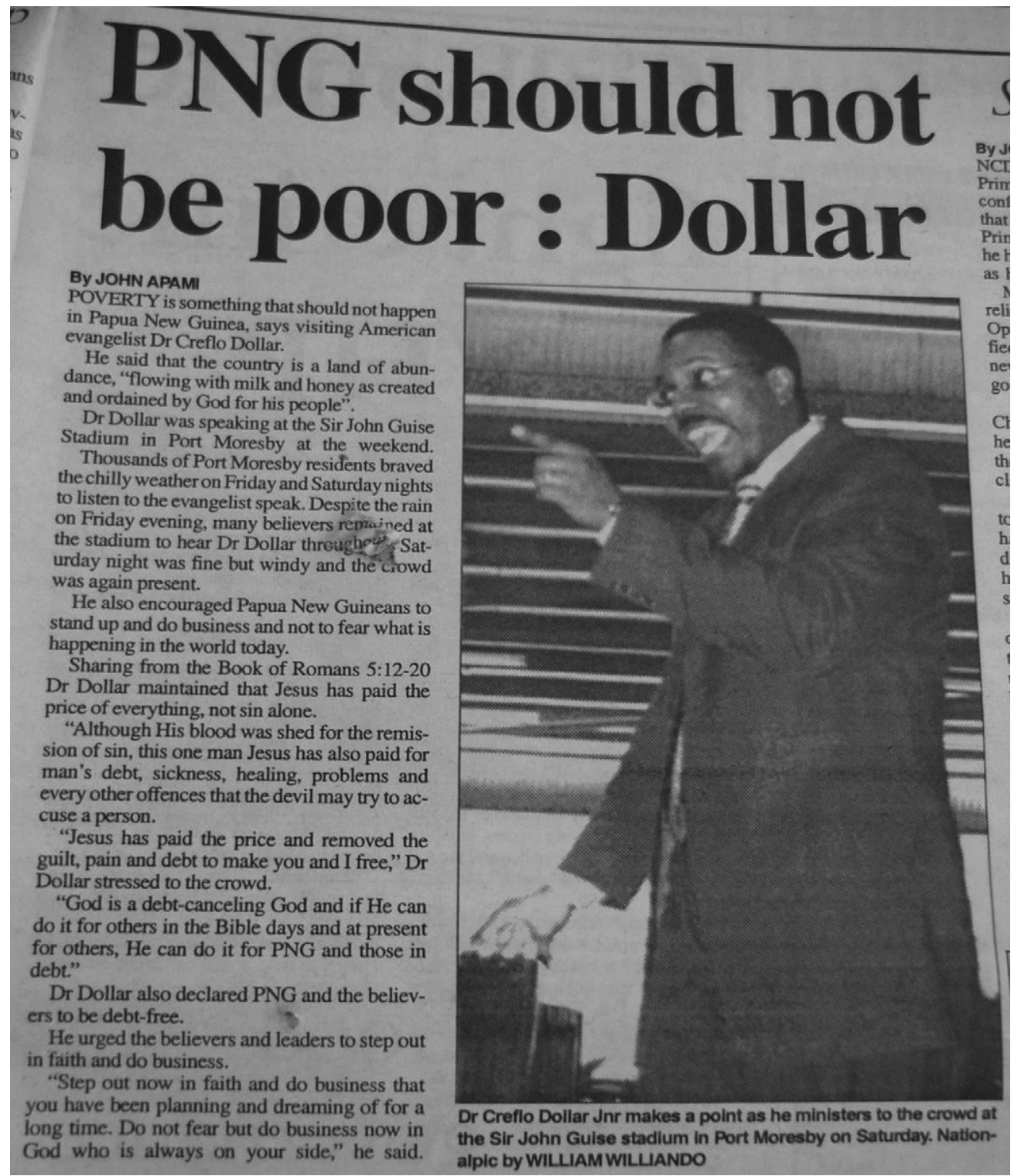

Figure 1: Apami 2001.

\section{EVANGELICAL CHRISTIANS AND THE CHARISMATIC STATE}

Pentecostal groups in PNG have succeeded in attracting a successful professional elite in PNG (Jorgensen 2005: 448), thus establishing informal networks within government bureaucracies and other centres of power. Because of their assumed moral superiority, Christian professionals are understood to have a unique mission to guide the nation and indeed to reclaim the entire 'social sphere' (Comaroff 2009:24; cf. Coleman 2000: 222-3). This effort to place Christians in key positions is not simply a form of nepotism or wantokism but is understood as a necessary step towards rectifying the corruption, poverty and misfortune that beset the nation. Once the nation undergoes the conversion expected of individual believers, thus placing 'Jesus Christ as the head of the nation', God's blessing will be restored and everyone will flourish 


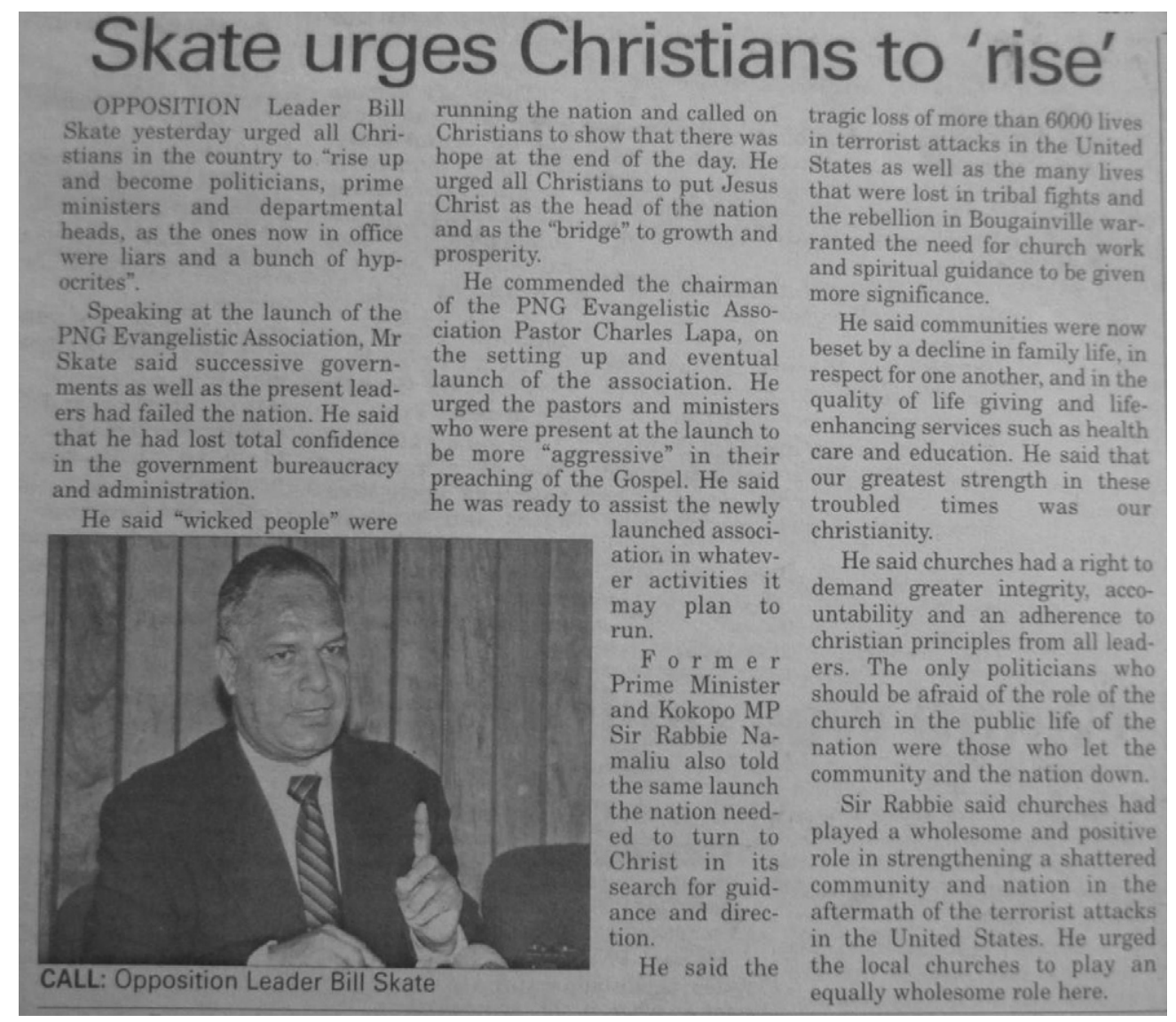

Figure 2: Post-Courier 25 Sep 2001.

again. Bill Skate, seeking legitimacy after losing the Prime Ministership, echoed these sentiments at the launch of the PNG Evangelistic Association (Figure 2).

As reported in the press, Skate's comments to the association endorsed popular critiques of politicians and high-level bureaucrats as corrupt (despite having supported U-Vistract and other fast money schemes when Prime Minister himself). ${ }^{5}$ For Skate, moral reform was required for the nation to flourish and this should be achieved by electing devout Christians to positions of influence. Skate's moralizing focus on individual character and religious credentials as the key to reviving national fortunes is itself typical of much public debate in PNG (Gibbs 2005; Eves 2008). It is important to understand PNG's distinctively Christian public realm, not as a retreat from the nation's fraught politics into a world of spiritual fantasy. Nor are religion and the secular state in any way separate domains (cf. Hermkens, this special issue). Rather, the Christian moral critique of the nation is one formulation of an alternate PNG modernity that draws on many of the same logics as those that underpin the state project of development. What may seem to be an overly personalised way of thinking about the state follows a logic described by James Holston (1999:616) as 'charismatic statecraft' where there is 'a connective correspondence between the good state of the ruler . . . and the good state of the realm'. This form of charismatic authority has an ancient pedigree and has long undergirded ideas of monarchy. Yet Holston argues that the charismatic state is not an archaism or traditional artefact but appears frequently too in great modernist programs of public works - 
such as his example of the construction of Brasilia as the planned capital of Brazil. In PNG, such projects are more experienced through laments of their absence because the state has failed to perform to expectations of development. This in turn implies problems with the leadership and the need for moral regeneration.

\section{FROM U-VISTRACT TO THE KINGDOM OF PAPALA}

These questions of charismatic statecraft assist in understanding the transformation of U-Vistract into Papala. Initially, Papala was introduced to U-Vistract investors as a spiritual realm 'like the Kingdom of God' but 'not a claim to physical territory' (O'Callaghan 2000). Yet even as this disembodied realm, Papala claimed the authority of a state against the PNG state. Papala was appealed to as the endorsing power behind U-Vistract in the face of the PNG Government's new opposition to the scheme. Papala was also presented as a chosen nation, similar to other Melanesian appropriations of Biblical prophesies (Hermkens, this special issue; Timmer 2012 and this issue).

When Musingku escaped to Bougainville to avoid prosecution for fraud and contempt of court, the Kingdom of Papala assumed a territorial dimension. Now centred in Tonu, Musingku's home village, relationships with separatist leader Francis Ona were crucial to his safety because of the instability of South Bougainville and because Ona did not accept the authority of the ABG or the PNG state. Indeed Ona had proclaimed his own state: the Republic of Me'ekamui. Musingku's insinuation into Ona's confidence culminated in the 2004 crowning of Ona and Musingku as kings of the Dual Kingdoms of Me'ekamui and Papala (Hermkens, this issue).

Musingku carefully presented Papala as a complementary realm that did not threaten Me'ekamui but had the unique status of 'Twin Kingdom'. In a 2005 article, 'Concept of Royal Twin Kingdoms', published in the U-Vistract propaganda magazine, Papala Chronicles, Musingku described the origins of Papala using the language of sovereignty and 'total financial independence'. This sovereignty is grounded in (supposed) Bougainvillean tradition disrupted by European colonialism. The relationship between the 'Twin Kingdoms' is explained in terms of complementary roles: Me'ekamui expelled the foreign system while Papala will establish 'the new and sovereign international government and banking system'. In further oblique descriptions of the complementary relationship, 'Me'ekamui is the hardware, Papala the software; Me'ekamui the body, Papala the spirit' (Musingku 2005). ${ }^{6}$ Musingku's terms are significant. He writes that 'Me'ekamui provides the government system whilst Papala provides the financial operating system'. Here financial systems become a form of sovereignty that constitutes the state. In the U-Vistract propaganda, the promised capacity to deliver prosperity for all is central to the scheme's performance of being like a state that can replace the existing 'government system'.

Separatist movements such as Me'ekamui aspire to secede from an unjust state to form a new just state and nation overseen by just rulers. It is not difficult to see how financial fraudsters could insert their programs into these kinds of utopian projects. A just state with just, God-fearing rulers might easily imply a just economy, just banks or just money and indeed these aspirations coalesced in the Kingdom of Papala as Musingku attempted to align his financial utopianism with Ona's Bougainvillean separatism.

U-Vistract's focus on international finance is distinctive. While the mission of the Chosen Nation to redeem the nations is familiar from the Bible, the mission of the Kingdom of Papala will be fulfilled through an imagined global banking system. Unlike Me'ekamui, Papala was not so much a separatist movement as a physically located base for transforming global financial systems, more akin to the Kingdom of Melchizedek promoted by the American 
swindler, Mark Pedley. In the early 1990s, Pedley targeted separatists in the Marshall Islands, Rotuma and New Zealand. In courting these groups, Pedley sought a territorial jurisdiction where he could register fraudulent insurance companies and financial schemes (Van Fossen 2002; cf Patterson 2011). There are no known links between Pedley and Musingku but both pseudo-states mimicked practices of state, notably in appearing to establish development banks and the like with titles designed to recall the World Bank, Asian Development Bank and so on. For example, in New Zealand Pedley took NZD 6 million from Chatham Islanders under the name of International Monetary Investments (IMI), a name chosen to mimic the International Monetary Fund (IMF) but which also resonated locally as 'Indigenous Maori Independence'. Similarly, Musingku launched a number of fake institutions, including the Royal Bank of Papala, the International Bank of Me'ekamui, the Royal Central Bank of Me'ekamui and the Royal Assembly of Nations and Kingdoms, a fictional alternative to the United Nations that very nearly succeeded in defrauding the Solomon Islands Government in 2003 (Cox 2012). Being seen like a state seems to entail being seen like an aid donor.

\section{MONARCHY AND MONEY: LOCALISED TRADITION, CHARISMATIC STATECRAFT AND GLOBAL FINANCE}

LiPuma (1995: 57f) has pointed to the importance of customary bases for contemporary nation-making projects in the Pacific (see also Jolly and Thomas 1992 and Otto and Thomas 1997). And indeed, for Papala's performance of being like the state to be believable it required a connection to Bougainvillean tradition (Regan 2010: 117). In a letter addressed to the Acting Prime Minister (Musingku 2000), an edited version of which was published (with an editorial disclaimer) in the National on 26 April 2000, Musingku claims customary origins for U-Vistract. U-Vistract's traditional precedents supposedly predate the PNG state as they are claimed to originate in various Bougainvillean chiefly practices of conciliation and exchange dating back to 1922. In this letter, Musingku also claimed links to Queen Elizabeth II, setting the scene for his later appropriation of royal titles.

In spite of U-Vistract's claims to tradition, statehood, and customary financial mechanisms, these were widely understood to have no substance in Bougainvillean history (Nash and Ogan 1990). Every Bougainvillean I have spoken to regards these claims as ridiculous and without customary foundation. But its claims to royalty did legitimate U-Vistract for some followers of the scheme. Both Musingku and Ona made claims to kingship that resonated for many in Bougainville, perhaps because of the biblical precedents of righteous rule and the currency of ideas about Bougainville as a holy nation (Hermkens, this issu8e). 'Does he come from a chiefly line?' I was asked by a Bougainvillean from a neighbouring area. Although thoroughly sceptical of U-Vistract as a fraud and finding the claims to kingship ridiculous, this person still left the possibility open that there was some customary (or class: Errington and Gewertz 2007: 108, n17) basis to Musingku's fantasy. This indeterminacy allowed outsiders scope to believe that claims to kingship might have some precedent. However, my interest is in how these ideas made sense to those not from Bougainville and who saw U-Vistract primarily as a financial institution.

Balthasar links sovereignty and money in another way as he defends Musingku's assumption of the title King. I have not seen this line of argument in any of the U-Vistract propaganda, so it appears to be Balthasar's own apologetic, developed to reassure doubters in Madang.

'King Peii' is using their language. It doesn't bother us, so we don't take much notice of these things. There's a Queen in England, so why not he becomes King in 
his own place because he has money? There's a King of Tonga, so why not? He also has a lot of money. He based it on his ancestors. Maybe he's calling himself the King because he's got the money. Likewise Queen Elizabeth has a lot of money - she's a rich woman, so we're all under her.

Balthasar regards Musingku's claims to kingship as none of his concern because they arise from Bougainvillean tradition and so are relevant to Bougainvilleans but not others: 'he becomes King in his own place because he has money'. There are regional precedents with the King of Tonga, while PNG, Australia and Solomon Islands are all constitutional monarchies, although, unlike its neighbours, PNG currency does not bear the head of the Sovereign. For Balthasar, Musingku's kingship makes sense because of the association between wealth and sovereignty. What gives Queen Elizabeth, PNG's Sovereign, her title if not her great wealth? If Musingku can deliver the amount of money that he promises, then surely he also has the right to call himself king, according to the traditions of 'his own place', even if these are only dimly understood by outsiders.

Papua New Guineans have seen progressions of state currencies and know the relationship between money and the state (Foster 1999). It is perhaps logical to think that a new type of abundant economy would require a new type of state. Indeed, before long U-Vistract was issuing its own currency: the Bougainville Kina (Gridneff 2010). Clark (1997) documents Huli of the Southern Highlands who believed that Queen Elizabeth made Australian money while Michael Somare made PNG currency. Lamenting the exit of the Australian colonial presence, Clark's Huli resented Somare's conceit in creating money and implicitly capturing the state and its resources. If Clark's example speaks of disillusionment with the state and estrangement from the true source of wealth, Balthasar anticipates the restoration of these connections through Musingku's kingly command of money.

Felix, an East Sepik resident of Madang who makes a good living as a carpenter, had joined U-Vistract some ten years before I interviewed him in 2009. Here he makes an association between wealth and Musingku's claims to kingship that is similar to Balthasar's argument:

Initially I got involved through my wife. She's a Madang lady. She came home and she'd heard some rumours at Modilon Hospital. People were saying you could invest K100 and get K1000 or K1000 and you'll get K100,000. One time she told me to go down to Tusbab [a beach in Madang town] and we heard that lady [the flamboyant Bougainvillean who was the U-Vistract agent for Madang] was talking about this money investment system. She said that Noah is a king and he' $d$ been in England and established a rollover or something with the Royal Stock Exchange and he was starting it all over and give to us. I think that's true, that's why I believe, so I start investing then.

Felix elided the British monarchy and stock exchange and was convinced of Musingku's connection with both, helped by some mystification in the form of financial jargon such as 'rollover'. In PNG, royalty, like finance, is transnational. It implies connections overseas that transcend the failing nation (cf. Foster 2006). Far from being a ludicrous claim that provokes scepticism and ridicule, as King, Noah becomes exactly the kind of person who would have money or be able to create money. The invocation of multiple forms of legitimacy ensures that they are mutually reinforcing. Owning and managing wealth are here characteristics of legitimate leadership. ${ }^{7}$

Felix imagines the kingly Musingku restoring the rightful links between monarch, people and prosperity. Here Holston's observation of charismatic statecraft is relevant: the state of the ruler reflects the state of the state. However in the U-Vistract performances of the state, the 
realm is expanded beyond the local to a global world that includes distant places where great wealth is produced and circulated. By travelling to England, the centre of legitimate royal status, Musingku could use his standing as a king to re-establish relations with the 'Royal Stock Exchange', thus initiating a flow of benefits to PNG. These connections between money and sovereignty made by Balthasar, Felix and by Clark's Huli reflect a this-worldly view of the economy that is quite realistic in some respects. PNG has no international financial centre comparable with London or New York. To prosper, better and more equitable connections with those centres are required.

U-Vistract's performances of globally connected sovereignty presented Musingku as a royal patron and donor of development assistance to PNG and other countries (cf. Cox 2009). The article below (Figure 3) claims that U-Vistract had loaned K100 million to the PNG Government and had agreements with Solomon Islands and the United States. The article portrays then Prime Minister, Michael Somare, as seeking assistance from U-Vistract. ${ }^{8}$ U-Vistract here assumes a role that mimics the ideal state of Australia as the dominant regional power and aid donor in the Pacific. PNG, on the other hand, is represented as a state in the bondage of dependency. Its leaders are not commensurate with Musingku's kingly status: Somare is treated dismissively and told that he can negotiate with Musingku's deputies, including his own appointed 'Governor General Sir Iairo Lasaro'. ${ }^{9}$ As Papala performs as a superior donor state, money is again asserted as the grounds of sovereignty. Indeed, the claim is that only U-Vistract can provide the means for PNG to become truly independent as a nation-state.

\section{Benign patrons: mimesis of the developmental state}

Unlike the failing government system, U-Vistract claimed to bring tangible benefits to the people. Papala Chronicles carried stories of roads being built, school fees being paid, of women learning small business skills and other indicators of the scheme's ability to realise development hopes. While these benefits were primarily imagined as bountiful payments to individual investors, after Musingku's return to Tonu, U-Vistract began to produce propaganda that represented it as an effective developmental state, even if the effects of this performative statecraft were only experienced as the public relations produced by a state and not as actual projects. Below is a Papala Chronicles article (Figure 4) announcing the payment of school fees by the benign King Peii II. Billed in the development industry language of a 'major assistance package', supposedly worth millions of Kina, Musingku is presented as the righteous ruler, acting as a generous donor - the way governments should be acting - for the benefit of the people. These payments were never made but the narrative presents Musingku making a performance of being an effective dispenser of national development. In fact, announcements like this were used to fleece more money out of investors around the country. Felix, the carpenter mentioned above, paid additional money, 'stamp duty', to register his children for payment of their school fees by the scam and fell for this two years in a row before realising that he had been fooled.

Reports of supposed initiatives like the one above were aligned to the expectations of investors that the state's role is to ensure the prosperity of its people by providing services and welfare (and the modern culture of government and donors announcing such initiatives in press releases published in the newspapers). Rebecca, Balthasar's wife who is also on the Madang U-Vistract committee, thought of the promised millions in her account as a means to deliver development:

We all come from villages and we have to think about our village people. So the government can't provide for people. Kids are walking for five hours to go to school, there are no roads. So we invest thinking we can do something better when U-Vistract pays us. 


\section{* Papala Chronicles}

Official Newspaper of The Royal Twin Kingdoms of Papala and Meekamui-Bougainville.

Issue 15

Week ending Friday 23 ral September 2005

\section{PNG PM, Somare, seeks dialogue with $\mathrm{U}-\mathrm{V}$}

By Michael Jagui

The Papua New Guinea Government has started dialogue with the $U$ -

Vistract organization- which could be deemed a breakthrough for both PNG and Bougainville.

This follows a grant of a K100 billion from U-Vistract to PNG, seen as much needed funds to break-away from the slavery of borrowings from the foreign controlled conventional system.

"The Prime Minister's officers contacted my office, informing that he (Sir Michael Somare) wanted to talk to me, and I told them to talk to my Prime Minister or my Govemor General first", said the U-V Principal Director and King of the Papala Kingdom on Bougainville, HM King David Peii II.

"I have appointed my chief governor for PNG, Sir James Wangi, and Governor General, Sir Iairo Lasaro, and they should talk to them", said the King.

However, King Peii II said he is satisfied that the PNG government has realized the work being done by U-V to establish the U-V Government and Monetory system in PNG and other countries around the world.

"If discussions for financial grants to PNG are finalized, they will be third after Solomon Islands and the United States to finalize agreements with us", he said.

He said the agreement with the USA was signed on the 19th of April 2004. for USD 3 billion, while the Solomon Island agreement is for SID350 million.

"In 2002 it took Solomon Islands

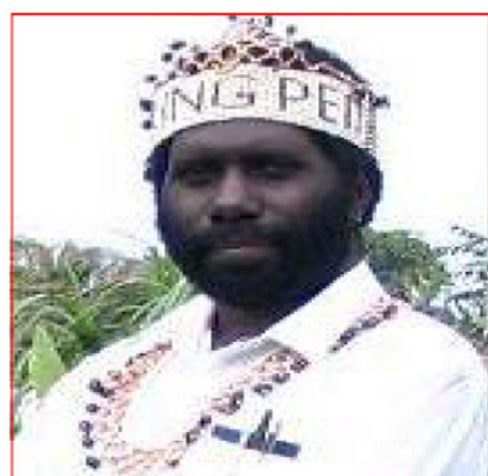

King tells Somare to talk with his PM

Government 6 weeks to investigate funds we have, before signing agreements with us", he said. $p c$

\begin{tabular}{l} 
In This Issue \\
** Peace Agree- \\
ment has failed. \\
Page 3. \\
** Port Moresby \\
and Rabaul next \\
to trial payout. \\
Page 4 \\
** King Francis \\
death signal new \\
era. Page 6 \\
* Crisis widows \\
appreciate school \\
fees. \\
Page 8. \\
\hline Scripture for \\
This Week \\
\hline Psalms 62: 10 \\
"If your riches \\
increase set not \\
your heart upon \\
it". \\
\hline
\end{tabular}

\section{Open Up Accounts Now}

Royal International Bank of Meekamui, with its payout offices throughout PNG and Bougainville are now ready to open personal savings, and other types of bank accounts.

And, customers have been assured that their monthly interest will be very much higher than the commercial banks.

Principal Director of UVistract which owns the RIBM, HM King David Peii II, who has directed the cease of money collections from helpers to open helpers accounts, says the U-V through its agencies including the RIBM is now ready to help people, and they must open normal accounts to benefit from its services.

RIBM has 21 account types with interest ranging from $10 \%$ to $20 \%$, some of which are Access, Surplus, Privy, savings, personal savings, company, Founding Members, and Royal International Classic, while it's high yield Trade Products are (cont page 3)

Figure 3: Jagui 2005a.

In addressing the development needs of the nation, investors take the place of the failed and discredited state that has neglected the needs of the people. In this respect, they imagine themselves able to become like a state. When investors receive their millions, they will be able to step in and do something decisive to rectify the situation. They will also be able to act as 


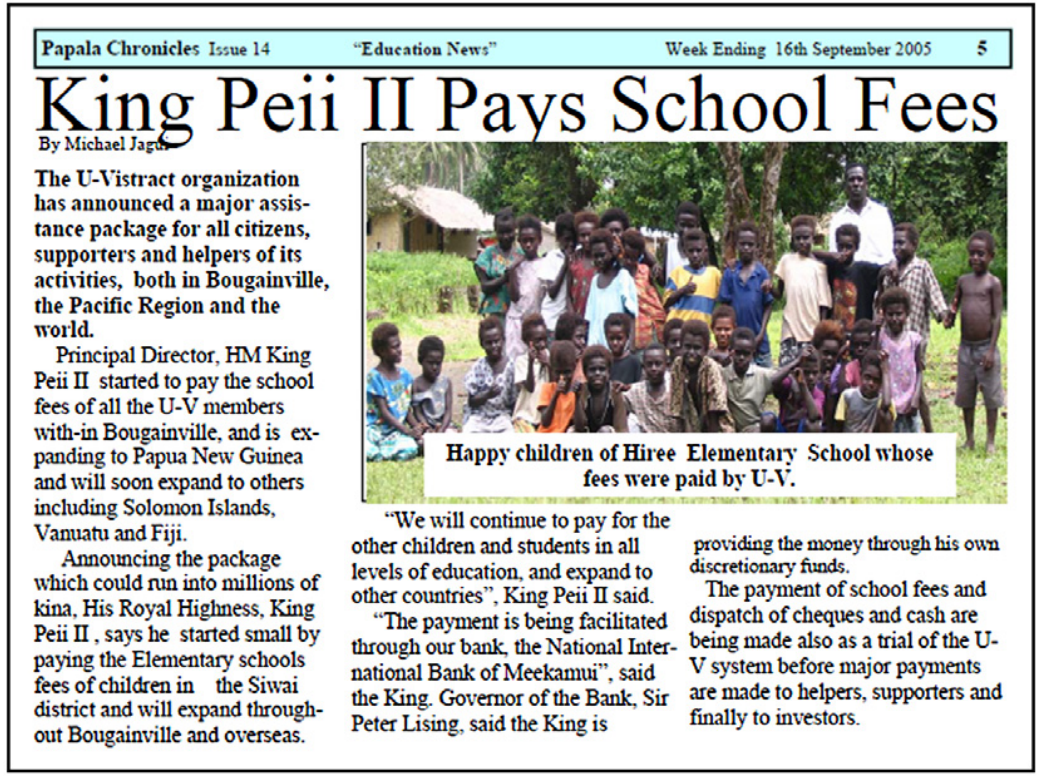

Figure 4: Jagui 2005b.

good politicians are expected to act: dispensing their money for the needs of the people, or at least their clients (Cox 2011).

There's a lot of money there. Old people, single mothers, they get paid by the government- not like here. Why don't we become like Australians? We see it on TV and in the newspapers. The leaders in Australia are really blessed to share things with the people. We saw the system worked, otherwise it would be happening and a lot of people would change their lifestyle because they've got money.

For Rebecca, Australian politicians provide the model of benign patronage: 'they are really blessed to share things with the people'.In Rebecca's imagination, Australian politicians are generous and indeed are 'blessed' to be so, meaning not that they come from a wealthier country with more efficient government systems but that they have the right moral attitudes towards their constituents and, by implication, a genuine personal relationship with God. These idealised Australian politicians are implicitly likened to Musingku who, Balthasar says, 'is a God-fearing man and reads the Bible every day'. Musingku's righteous persona as a humble and withdrawn prophet is a performance of being a different kind of leader, a 'servant leader' embodying the Biblical type of the suffering servant (Isaiah 53). Musingku's own writings (e.g. Musingku 2009) deliberately play on these images and use Biblical language to create an aura of mystery about his person and establish him as a moral exemplar. Unlike the 'pregnant with twins' beer bellies of politicians (Gewertz and Errington 2010: 114) that signify their greed and self-indulgence, Noah's virtuous, even holy, persona creates a strong foundation of Christian trustworthiness. Political leadership is understood as performance of the charismatic state. U-Vistract established its credibility as an alternative banking system by playing to these views and presenting itself as a Christian agent of moral reform led by a king who embodied those values.

Rebecca's lament that 'it is very hard for the people' is not simply for her own kin; it is located explicitly within the context of the failure of post-colonial PNG governments to fulfil 
their narratives of development for the benefit of the people. In the place of government, $\mathrm{U}$-Vistract offered the promise of the private sector coming to the rescue, unlocking the wealth of global share markets and putting it to good use through Christian patrons, led by King Peii II, who would dispense development to their rural kin and even have enough money to provide them with independent livelihoods.

This framework is not simply Christian parochialism or naïve inability to conceive of depersonalised institutions. The underlying logic relates to the centrality of trust in abstract systems such as governments or financial institutions (Giddens 1990). As Foster (2002: 243) argues, embedding the PNG state in Melanesian conventions of reciprocity has actually eroded people's trust in government. By re-embedding the nation and its money in a Christian ethic, U-Vistract addressed these questions of trust through a moral narrative, albeit for the purpose of defrauding those who placed their trust in it. However, rebuilding a trustworthy national scale (cf. Tsing 2000) was not a project of rejecting tradition in favour of transnational Christian visions of modernity. For U-Vistract to lay claim to national confidence, it also required the appearance of a local grounding in traditions of place, alongside Christian moral rigorism and being seen like a developmental state that could deliver services.

Anthropologists such as Timmer (2010) have documented marginal groups whose experiences of historical powerlessness in the face of injustice have led to rituals of redemption through mimesis of state mechanisms of justice, including drafting constitutions. U-Vistract, however, mimicked not state mechanisms of justice but mechanisms of finance, foregrounding broader PNG imaginings of the state as the distributor of wealth. The narrative is not simply one of individuals accumulating wealth, which would be morally suspect. Rather, the magical money of U-Vistract requires the magic of the state in order to resituate individual desires for money and wealth into the national narrative of development and to re-engage those individuals as moral agents in this project. U-Vistract awakened new possibilities for moral agency among those disillusioned with the state of development. Through U-Vistract, working class Papua New Guineans like Rebecca and Balthasar could enter into a new narrative of modernity and of national development in which they could imagine themselves playing a meaningful part as morally purposeful agents of development.

\section{CONCLUSION: THE SCAM BECOMING LIKE THE STATE}

The material in this paper highlights elements of popular discourses of the state that are often ignored in academic studies that are centred in legal or constitutional written imaginings of the state or on the Weberian grounding of the state in the monopoly of violence (Hansen and Stepputat 2006). Here economic systems are more fundamental and resonate with the unfulfilled promise of development, not to mention the lived experiences of law and order in PNG where it is far from clear that the state has any monopoly of violence.

U-Vistract scammed its investors, first by giving the appearance of being able to pay the spectacularly high returns promised and then by weaving elaborate narratives that explained why the money had not been paid but would be coming soon. It drew upon existing concerns of working class Papua New Guineans: discontent with the state and with the state of development across the country. For many, their financial investments became investments of their moral selves and their hopes for a better society. The Christian reform of global finance was to replace the existing corrupt and ineffective government system. In the process the money scheme began to perform the appearances of a state: U-Vistract morphed into Papala.

U-Vistract began with state patronage and courted many Bougainvillean leaders but, as the PNG Government changed and became hostile to the fast money schemes, it became necessary for U-Vistract to critique the state and its financial institutions. In doing so, it used 
ideas of money and development to delegitimise the PNG Government and, in place of the postcolonial nation state, re-founded itself as a reformed Christian state: one with transnational Christian links that allow it to transcend the constraints of dependency imposed by neo-colonial capitalism, but still following the state's narratives of progress, development, and access to modernity. Some of the script of this narrative was already written: the state's failings made it seem like a false state to many (cf. Bubandt 2009). If the state was already becoming like a scam, the groundwork was prepared for a scam to become like a true Christian state.

\section{ACKNOWLEDGEMENTS}

I thank the editors for a stimulating discussion of the magic of the state and for their comments on earlier drafts. I also thank Martha Macintyre for her helpful suggestions.

\section{NOTES}

1 Ponzi schemes are named for the Italian-American swindler Charles Ponzi. In 1919-20, he drew in 100,000s of people on the promise of $50 \%$ quarterly returns on a fraudulent investment scheme based on brokerage of postage coupons. In his case and for subsequent Ponzi schemes, the returns paid to investors were simply the contributions of new recruits. "Pyramid scheme" has become a blanket term for such scams and refers to the implicit pyramidal structure of recruitment. Some schemes, such as the Italian scam, Pentagono, which spread through PNG and Solomon Islands in the early 1990s had an explicit pyramidal structure where participants would only be paid once they had recruited a specified number of new investors. U-Vistract, however, recruited by word of mouth as people shared the news that someone they knew had been paid. In PNG, 'pyramid scheme' or 'fast money scheme' are terms preferred over 'Ponzi scheme', which I have not heard used there.

2 At the time of writing (Jan 2013), one Kina was equivalent to 45 Australian cents. When the PNG Government intervened in the fast money rush in 1999, one Kina was worth 51.8 Australian cents.

3 For more on Creflo Dollar, visit www.creflodollarministries.org. To my knowledge there is no academic analysis of Dollar's ministry. Dollar works in concert with Kenneth Copeland, one of the founders of the faith gospel (Gifford 2001).

4 Gibbs (2005) describes the 1999 visit of international prosperity evangelist Benny Hinn who was funded by then Prime Minister Bill Skate.

5 According to my informants, like many pastors of the large Pentecostal churches, Pastor Charles Lapa was also heavily involved with U-Vistract and used Sunday worship to promote the scheme.

6 In this equation of finance and spirit, I detect an affinity between the spiritualised and transterritorial nature of Kingdom of Papala and the immaterial circulations of financialised money through global share markets and financial trading (LiPuma and Lee 2004; Cox 2012).

7 Compare Sahlins's 'caricature' of Melanesian bigmen (1963). This command of wealth may even reflect the reproductive capacities of money itself (Robbins and Akin 1999:23; Foster 2002:244).

8 In fact the reverse was true: Musingku had sought Somare's protection and been rebuffed with the Prime Minister issuing another warning against fast money schemes (Kenneth 2003).

9 Lasaro was the Treasurer in the Skate Government who made fast money schemes exempt from the requirements of the Financial Institutions Act.

\section{REFERENCES}

APAMI, J. 2001. PNG should not be poor: Dollar. The National, 10 Dec 2001.

BAINTON, N. 2011. 'Are you viable?' Personal avarice, collective antagonism and grassroots development in Papua New Guinea. In M. Patterson and M. Macintyre (eds). Managing Modernity in the Western Pacific. St Lucia: University of Queensland Press, pp. 31-259.

BAINTON, N., and J. COX. 2009. Parallel states, parallel economies: legitimacy and prosperity in Papua New Guinea. State, Society and Governance in Melanesia Discussion Paper 2009/5. Canberra: Australian National University, Research School of Pacific and Asian Studies.

BUBANDT, N. 2009. From the enemy's point of view: violence, empathy, and the ethnography of fakes. Current Anthropology 24(3): 533-88

CLARK, J. 1997. Imagining the state, or tribalism and the arts of memory in the Highlands of Papua New Guinea. In Otto, Ton and Nicholas Thomas (eds). 1997. Narratives of Nation in the South Pacific. Amsterdam: Harwood Academic Publishing, pp. 65-91.

COLEMAN, S. 2000. The Globalisation of Charismatic Christianity: Spreading the Gospel of Prosperity. Cambridge: Cambridge University Press.

COMAROFF, J. 2009. The politics of conviction: faith on the neo-liberal frontier. Social Analysis 53(1): 17-38. 
COMAROFF, J., and J. L. COMAROFF. 1999. Occult economies and the violence of abstraction: notes from the South African post-colony. American Ethnologist 26(2): 279-303.

COX, J. 2009. Active citizenship or passive clientelism: accountability and development in Solomon Islands. Development in Practice 19(8): 964-980.

2011. Prosperity, nation and consumption: fast money schemes in Papua New Guinea. In Mary Patterson and Martha Macintyre (eds). Managing Modernity in the Western Pacific. St Lucia: University of Queensland Press, pp.172-200.

2012. Deception and Disillusionment: Fast Money Schemes in Papua New Guinea. PhD Thesis. Melbourne: University of Melbourne.

ERRINGTON, F., and GEWERTZ, D. 2007. Reconfiguring amity at Ramu Sugar Limited”. In John Barker (ed), The Anthropology of Morality in Melanesia and Beyond. Aldershot: Ashgate Publishing: 93-109.

EVES, R. 2008. Cultivating Christian civil society: fundamentalist Christianity, politics and governance in Papua New Guinea. State Society and Governance in Melanesia Discussion Paper 2008/8. Canberra: Australian National University, Research School of Pacific and Asian Studies.

FOSTER, R. 1999. In God we trust: the legitimacy of Melanesian currencies. In Akin and Robbins (eds). Money and Modernity: State and local Currencies in Melanesia. Pittsburgh: University of Pittsburgh Press, pp. 164-191.

2002. Bargains with modernity in Melanesia and elsewhere. Anthropological Theory 2(2): 233-251.

2006. From Trobriand cricket to rugby nation: The mission of sport in Papua New Guinea. International Journal of the History of Sport 23(5):739-58.

GEWERTZ, D., and F. ERRINGTON. 2010. Cheap Meat. Flap Food Nations in the Pacific Islands. Berkeley and Los Angeles: University of California Press.

GIBBS, P. 2005. Political discourse and religious narratives of Church and State in Papua New Guinea. State Society and Governance in Melanesia Working Paper 2005/1. Canberra: Australian National University, Research School of Pacific and Asian Studies.

GIDDENS, A. 1990. The Consequences of Modernity. Cambridge: Polity Press.

GIFFORD, P. 2001. The complex provenance of some elements of African Pentecostal theology. In A. Corten and R. Marshall-Fratani (eds). Between Babel and Pentecost: Transnational Pentecostalism in Africa and Latin America. Bloomington and Indianapolis: Indiana University Press, pp. 62-79.

GODDARD, M.. 2005. The Unseen City: Anthropological Perspectives on Port Moresby, Papua New Guinea. Canberra: Pandanus Books, Australian National University.

HANSEN, T., and F. STEPPUTAT. 2006. Sovereignty Revisited. Annual Review of Anthropology 35: 295-316.

HART, K. 1986. Heads or tails? Two sides of the coin. Man (N. S.) 21(4): 637-656.

HOLSTON, J. 1999. Alternative modernities: statecraft and religious imagination in the Valley of the Dawn. American Ethnologist 26(3): 605-631.

JAGUI. M. 2005a. King Pei II pays school fees. Papala Chronicles 14. Fri 16 Sep.

2005b. PNG PM Somare seeks dialogue with UV. Papala Chronicles 15. Fri 23 Sep.

JOLLY, M., and N. THOMAS. 1992. Introduction. Oceania 62(4): 241-248.

JORGENSEN, D. 2005. Third wave evangelism and the politics of the global in Papua New Guinea: Spiritual Warfare and the Recreation of Place in Telefolmin. Oceania 75(4): 444-460.

KENNETH, G. 2003. PM Warns Against PNG Money Scams. Post-Courier, 25 Sep.

KOIM, S. 2009. What about the rest of the public servants? Post-Courier, 1 Apr.

LIPUMA, E. 1995. The formation of nation-states and national cultures in Oceania. In R. Foster (ed). Nation-Making: Emergent Identities in Postcolonial Melanesia, pp. 33-68.

LIPUMA, E., and B. LEE. 2004. Financial Derivatives and the Globalization of Risk. Durham and London: Duke University Press.

MACINTYRE. M. 2011. Money changes everything: Papua New Guinean women in the modern economy. In M. Patterson and M. Macintyre (eds). Managing Modernity in the Western Pacific. St Lucia: University of Queensland Press, pp. 90-120.

MONSELL-DAVIS, M. 1993. Urban exchange: safety-net or disincentive? Canberra Anthropology 16(2): 45-66.

MUSARAJ, S. 2011. Tales from Albarado: the materiality of pyramid schemes in postsocialist Albania. Cultural Anthropology 26(1): 84-110.

MUSINGKU, N. 2000. Independent state of U-Vistract. Country within a country and Triune Government System. Unpublished letter dated 21 Apr.

2005. Concept of Royal Twin Kingdoms. Papala Chronicles 2. Fri 8 April.

2009. Most Wanted Man. http://nmusingku.blogspot.com/2009/06/hidden-treasure.html. Accessed 21 May 2010.

NASH, J., and E. OGAN. 1990. The red and the black: Bougainvillean perceptions of other Papua New Guineans. Pacific Studies 13(2): 1-17.

O'CALlaGHAN, M.-L. 2000. Sinking Noah's Ark of Funny Money. The Australian, 6 May.

OTTO, T., and N. THOMAS (eds). 1997. Narratives of Nation in the South Pacific. Amsterdam: Harwood Academic Publishing.

PATTERSON, M. 2011. Enchanted economies in the Pacific and beyond. In M. Patterson and M. Macintyre (eds). Managing Modernity in the Western Pacific. St Lucia: University of Queensland Press, pp. 59-89.

POST-COURIER. 1999. Our window of hope: Kabui, Post-Courier 26 Aug

2001. U-Vistract - Change and get paid. 31 May

2001. Skate urges Christians to rise. 25 Sep

2007. 60,000 live on loan cash. 20 Sep 
REED, A. 2003. Papua New Guinea's Last Place: Experiences of Constraint in a Postcolonial Prison. New York and Oxford: Berghahn Books.

REGAN, A. 2010. Light Intervention: Lessons from Bougainville. Washington: United States Institute of Peace Press.

ROBBINS, J. 2004a. Becoming Sinners: Christianity and Moral Torment in a Papua New Guinea Society. Berkeley: University of California Press.

2004b. The globalisation of Pentecostal and Charismatic Christianity. Annual Review of Anthropology, 33: 117-43.

ROBBINS, J., and D. AKIN. 1999. "An introduction to Melanesian currencies: agency, identity, and social reproduction". In David Akin and Joel Robbins (eds). Money and Modernity: State and local Currencies in Melanesia. Pittsburgh: University of Pittsburgh Press, pp. 1-40.

SAHLINS, M. 1963. "Poor man, rich man, big man, chief: political types in Melanesia and Polynesia". Comparative Studies in Society and History 5(3): 285-303.

TIMMER, J. 2010. "Being Seen Like the State: Emulations of Legal Culture in Customary Labor and Tenure Arrangements in East Kalimantan, Indonesia". American Ethnologist 37(4): 703-712.

2012. Straightening the Path from the Ends of the Earth: The Deep Sea Canoe Movement in Solomon Islands. In Lenore Manderson, Wendy Smith, and Matthew Tomlinson (eds), Flows of Faith: Religious reach and community in Asia and the Pacific, pp. 201-214. Dordrecht and New York: Springer Publishing Company.

TSING, A. 2000. "Inside the economy of appearances". Public Culture 12(1): 115-144.

VAN FOSSEN, A. 2002. "Financial frauds and pseudo-states in the Pacific Islands". Crime, Law and Social Change. 37: $357-378$.

VERDERY, K. 1995. "Faith, Hope and Caritas in the Land of the Pyramids: Romania, 1990 to 1994". Comparative Studies in Society and History, 37(4): 625-699. 